\title{
KLASIFIKASI PENYAKIT PNEUMONIA MENGGUNAKAN METODE CONVOLUTIONAL NEURAL NETWORK DENGAN OPTIMASI ADAPTIVE MOMENTUM ${ }^{\star}$
}

\author{
Lingga Aji Andika ${ }^{1}$, Hasih Pratiwi², and Sri Sulistijowati Handajani ${ }^{3}$
}

\begin{abstract}
1Department of Statistics, Universitas Sebelas Maret (UNS), Indonesia, linggaajiandika@gmail.com 2Department of Statistics, Universitas Sebelas Maret (UNS), Indonesia, hasihpratiwi@gmail.com 3Department of Statistics, Universitas Sebelas Maret (UNS), Indonesia, rr_ssh@staff.uns.ac.id
\end{abstract}

Indonesian Journal of Statistics and Its Applications (eISSN:2599-0802) Vol 3 No 3 (2019), 331 - 340

Copyright (@ 2019 Lingga Aji Andika, Hasih Pratiwi, and Sri Sulistijowati Handajani. This is an openaccess article distributed under the Creative Commons Attribution License, which permits unrestricted use, distribution, and reproduction in any medium, provided the original work is properly cited.

\begin{abstract}
Pneumonia is an infection of the bacterium Streptococcus pneumoniae which causes inflammation in the air bag in one or both lungs. Pneumonia is a disease that can spread through the patient's air splashes. Pneumonia can be dangerous because it can cause death, therefore it is necessary to have early detection using chest radiograph images to determine the symptoms of pneumonia. Diagnosis using a chest radiograph image manually by medical personnel or a doctor requires a long time, even difficult to detect pneumonia disase. Convolutional neural network (CNN) is a deep learning method that adopts the performance of human brain neurons called neural network and convolution functions to classify images. CNN can also help classify pneumonia based on chest radiograph images. This study used data from Labeled Optical Coherence Tomography (OCT) and Chest X-Ray Images for Classification as many as 5860 images entered into two classes, namely normal and pneumonia, then 2400 data samples were taken using simple random sampling. This study uses adaptive momentum optimization (Adam) which serves to improve the accuracy of the model. Adam optimization is a development of existing optimizations such as Stochastic gradient descent (SGD), AdaGard, and RMSProp. The classification results of the models built were $99.98 \%$ for training data with 100 epochs, and accuracy in the test data was $78 \%$ which means that the model was able to qualify $78 \%$ of the test data into normal classes and pneumonia appropriately.
\end{abstract}

Keywords: adaptive momentum, classification, convolutional neural network, pneumonia.

"Received Aug 2019; Accepted Oct 2019; Published online on Oct 2019 


\section{Pendahuluan}

Paru-paru merupakan organ pada sistem pernapasan manusia yang berfungsi sebagai pertukaran oksigen dengan karbondioksida di dalam darah. Penurunan kualitas udara di dunia termasuk di Indonesia, berdampak pada meningkatnya resiko terkena penyakit paru-paru. Penyakit paru-paru yang sering dijumpai adalah paru-paru basah.

Paru-paru basah atau pneumonia adalah bentuk infeksi pernapasan akut yang menyerang paru-paru. Paru-paru terdiri dari kantung-kantung kecil yang disebut alveoli, yang terisi air ketika orang sehat bernafas. Ketika seseorang menderita radang paru-paru, alveoli dipenuhi dengan nanah dan cairan, yang membuat pernafasan terasa menyakitkan dan membatasi asupan oksigen. Pneumonia adalah penyebab kematian menular tunggal terbesar pada anak-anak di seluruh dunia. Pneumonia menyebabkan 920.136 anak kasus kematian di bawah usia 5 tahun pada 2015, terhitung $16 \%$ dari semua anak di bawah lima tahun. Pneumonia paling umum dijumpai di Asia Selatan dan Afrika sub-Sahara. Pneumonia disebabkan oleh sejumlah infeksi, termasuk virus, bakteri, dan jamur, yang paling umum adalah streptococcus pneumoniae (WHO, 2016).

Diagnosa dini pneumonia berdampak besar bagi nyawa seorang pasien. Diagnosa pneumonia pada umumnya dilakukan secara klinis (gejala fisik oleh dokter). Selain itu, penyakit pneumonia juga dapat didiagnosa melalui foto chest radiograph, CT scan, dan MRI. Pemeriksaan chest radiograph adalah salah satu pemeriksaan pencitraan medis yang paling sering digunakan karena lebih terjangkau. Pembacaan foto chest radiograph memiliki kekurangan, yaitu sulit terdeteksinya penyakit, sehingga memerlukan waku lama sebelum tenaga medis atau dokter mendiagnosis penyakit yang diderita oleh pasien. Salah satu metode untuk mengatasi masalah tersebut adalah dengan mengklasifikasikan citra chest radiograph ke dalam kelas tertentu dengan menggunakan machine learning. Metode yang digunakan memproses data adalah multilayer perceptron (MLP) (Rizal et al., 2017). MLP memiliki kekurangan untuk beberapa jenis data, terutama untuk gambar, akan tetapi MLP tidak diadaptasi dengan baik sehingga kehilangan informasi spasial yang terkandung dalam gambar. Deep learning adalah salah satu cabang ilmu dari pembelajaran mesin atau yang kerap disebut sebagai machine learning. Deep learning merupakan teknik disruptif yang mengubah paradigma lama dalam machine learning. Deep learning memiliki tingkat akurasi yang jauh lebih tinggi dibandingkan dengan shallow learning, yaitu metode machine learning yang ada sebelumnya seperti MLP (Cireşan et al., 2012).

Data yang berupa citra chest radiograph, merupakan data gambar dua dimensi yang dapat diproses menggunakan deep learning dengan metode Convolutional Neural Network (CNN) (Santos et al., 2007). CNN adalah jaringan saraf atau neural network yang menggunakan konvolusi sebagai pengganti perkalian matriks umum, dimana paling tidak terdapat satu konvolusi di setiap layer. CNN mampu mengklasifikasikan citra dengan tingkat akurasi tinggi karena dapat mengurangi sejumlah parameter bebas serta dapat menangani deformasi gambar input seperti translasi, rotasi dan skala. Optimasi pada CNN dapat membantu meningkatkan akurasi, salah satunya adalah adaptive moments atau adam (Kingma \& Ba, 2014).

Saraiva et al. (2019) membahas tentang klasifikasi penyakit pneumonia pada anakanak dengan menggunakan convolutional neural network. Penelitian tersebut menggunakan validasi silang $k$-fold untuk mengevaluasi kapasitas generalisasi model dan bertujuan untuk meningkatkan akurasi dengan validasi silang $k$-fold dengan akurasi rata-rata sebesar $95,30 \%$. Akan tetapi penelitian tersebut belum ada pemilihan model terbaik dengan membandingkan jumlah epochs untuk model training sehingga didapatkan klasifikasi CNN dengan akurasi tertinggi, selain itu pembangunan arsitektur 
model menggunakan base model yang sudah ada. Penelitian ini akan dibandingkan jumlah epochs untuk mengklasifikasikan penyakit paru-paru dengan citra chest radiograph dengan melihat tingkat akurasi tertinggi dari optimasi model yang dibangun serta arsitektur model dari awal.

\section{Metodologi}

\subsection{Bahan dan Data}

Data yang digunakan dalam penelitian ini merupakan data sekunder yang berasal dari Labeled Optical Coherence Tomography (OCT) and Chest X-Ray Images for Classification (Kermany et al., 2018). Data berupa gambar dengan berbagai ukuran. Data terdiri dari dua kelas yaitu kondisi pneumonia dan kondisi normal dengan jumlah 5860 data.

\subsection{Metode Penelitian}

Langkah-langkah yang dilakukan untuk mengklasifikasikan penyakit pneumonia dengan citra chest radiograph menggunakan convolution neural network adalah sebagai berikut:

1) Melakukan prepocessing data

Sebelum data dianalisis perlu dilakukan preprocesing data, yang bertujuan untuk melihat karakteristik data. Karakteristik data merupakan gambaran umum bagaimana komputer membaca sebuah gambar menjadi array yang bermakna untuk proses selanjutnya seperti adanya efek spasial dalam data gambar. Preprocessing juga membagi data ke dalam tiga set data yaitu training data, validasi data, serta test data yang bertujuan untuk pemodelan di langkah selanjutnya.

2) Melakukan pemodelan CNN pada data training.

Jaringan konvolusional yang juga dikenal sebagai jaringan saraf konvolusional, atau Convolutional Neural Network (CNN), adalah jenis jaringan saraf khusus untuk memproses data yang memiliki kemiripan grid topology. Nama CNN menunjukkan bahwa jaringan tersebut menggunakan operasi matematika yang disebut konvolusi. CNN merupakan jaringan saraf yang menggunakan konvolusi sebagai ganti dari penerapan matriks umum dimana paling tidak terdapat satu konvolusi di setiap layer (Goodfellow et al., 2016). Dalam matematika, konvolusi adalah operasi matematika pada dua fungsi untuk menghasilkan fungsi ketiga yang mengekspresikan bagaimana bentuk satu dimodifikasi oleh yang lain. Istilah konvolusi mengacu pada fungsi hasil dan proses penghitungannya (Romero et al., 2016).

Sebagai contoh seseorang menembakkan sensor laser untuk melacak sebuah pesawat luar angkasa yang memberikan output tunggal $x(t)$ dimana t adalah waktu ke- $t$ dimana $x$ dan $t$ bernilai rill. Untuk memperoleh perkiraan posisi pesawat ruang angkasa yang tidak terlalu berisik, digunakan rata-rata beberapa pengukuran. Karena, pengukuran yang terbaru lebih relevan, maka rata-rata tertimbang digunakan untuk pembobot pengukuran baru. Fungsi ini disebut fungsi pembobotan $w(a)$ dengan a usia pengukuran. Jika digunakan secara terus menerus, maka didapatkan fungsi baru $s$ yang memeberikan estimasi smooth tentang posisi pesawat, sehingga persamaan kontinu dapat dituliskan sebagai berikut (Goodfellow et al., 2016):

$$
s(t)=\int x(a) w(t-a) d a
$$


Dalam terminologi jaringan konvolusional, fungi $x$ ke jaringan sering disebut input, fungsi $w$ disebut kernel, dan output dihasilkan terkadang berupa feature map atau peta aktivasi (activation map) yaitu pemetaan dimana fitur tertentu ditemukan dalam gambar. Karena diasumsikan $t$ dihitung per detik sehingga $t$ adalah bilagan bulat, maka persamaan konvolusi diskrit:

$$
s(t)=(x * w)(t)=\sum_{a=-\infty}^{\infty} x(a) w(t-a)
$$

Pemodelan data training dibangun menggunakan beberapa pengulanggan convolution layer dan pooling layer yang kemudian diakhiri dengan fully connected layer untuk membangun arsitektur pemodelan dengan akurasi tinggi. Secara terpisah fungsi masing-masing lapisan dijelaskan sebagai berikut:

a. Lapisan konvolusi (convolution layer) adalah bagian inti dari CNN dimana sebagian komputasi dilakukan di lapisan ini.

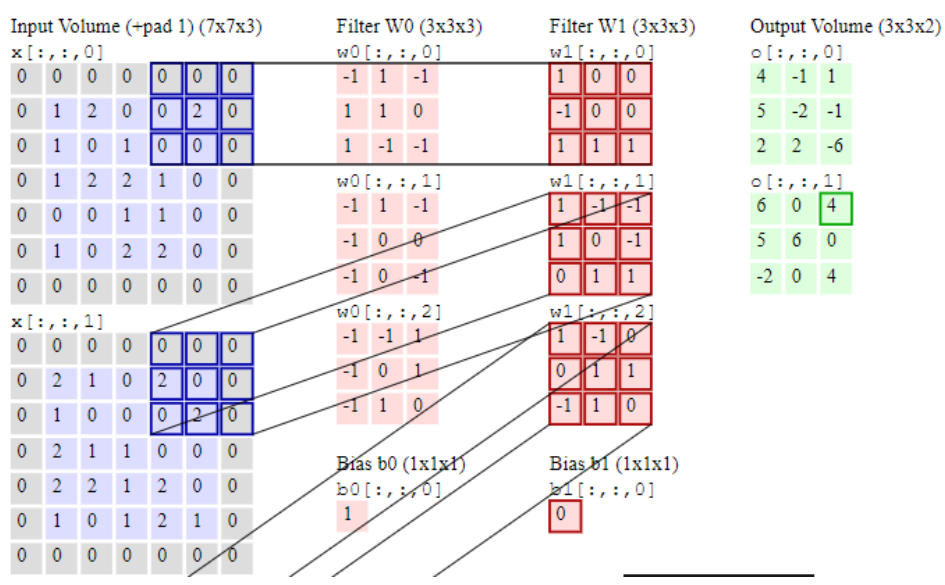

Gambar 1: Convolution Layer (Li et al., 2019).

Gambar 1 menunjukkan cara kerja dari konvolusi layer. Output didapat dari konvolusi kernel terhadap bagian dari gambar. Kemudian, kernel bergerak dengan jumlah $S$ piksel, $S$ yang disebut stride. Ketika langkahnya kecil, didapat informasi redundant. Terkadang input ditambahkan zero padding $(\mathrm{P})$, yang merupakan margin berisi nilai nol di sekitar gambar untuk mengontrol ukuran output. Diasumsikan bahwa diterapkan $\mathrm{K}$ kernel (juga disebut filter), masing-masing berukuran $k \times k$ pada gambar, dimana $k=F$ adalah tingkat spasial. Jika ukuran gambar input adalah $W_{i} \times H_{i} \times C_{i}\left(W_{i}\right.$ menunjukkan lebar, $H_{i}$ tinggi, dan $C_{i}$ jumlah channels atau kedalaman (depth), biasanya $C_{i}=3$ (Red, Green, Blue)), volume output adalah $W_{0} \times H_{0} \times C_{0}$, dimana $C_{0}$ sesuai dengan banyaknya kernel $\mathrm{K}$, sehingga didapat ringkasan konvolusi layer:

$$
\begin{gathered}
W_{0}=\frac{W_{i}-F+2 P}{S}+1 \\
H_{0}=\frac{H_{i}-F+2 P}{S}+1 \\
C_{0}=K
\end{gathered}
$$


b. Lapisan pooling berfungsi secara progresif mengurangi ukuran representasi spasial sehingga mereduksi jumlah parameter dan perhitungan dalam jaringan yang disebut juga subsampling, dan juga mengontrol overfitting (Scherer et al., 2010). Pooling layer digunakan secara berkala diantara convolution layer. Max pooling adalah pooling layer yang mengambil nilai maksimum dari setiap operasi kernel dengan input. Max pooling lebih banyak digunakan dibandingan pooling yang lain seperti average pooling. Gambar 2 menjelaskan penerapan max pooling.

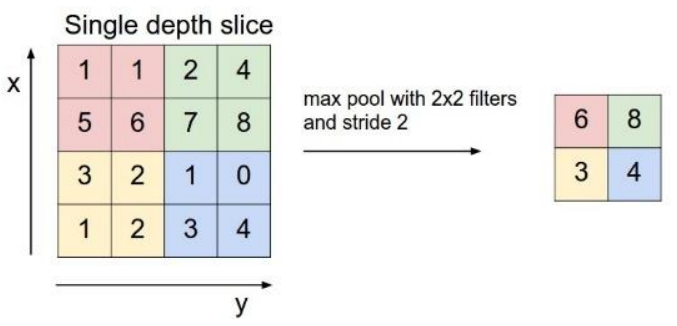

Gambar 2: Max Pooling (Li et al., 2019).

c. Layer terakhir pada proses convolotution neural network adalah fully connected layer yang berfungsi mengubah multidimensional array ke dalam sebuah vektor. Setiap neuron pada lapisan konvolusi perlu ditransformasi menjadi data satu dimensi terlebih dahulu sebelum dapat dimasukkan ke dalam sebuah fullyconnected layer. Karena hal tersebut menyebabkan data kehilangan informasi spasialnya dan tidak reversibel, sedangkan fully-connected layer hanya dapat diimplementasikan di akhir jaringan (Oyedotun \& Khashman, 2017). Aktivasi dari layer ini dapat dihitung dengan perkalian matriks yang diikuti bias (Gambar 3).

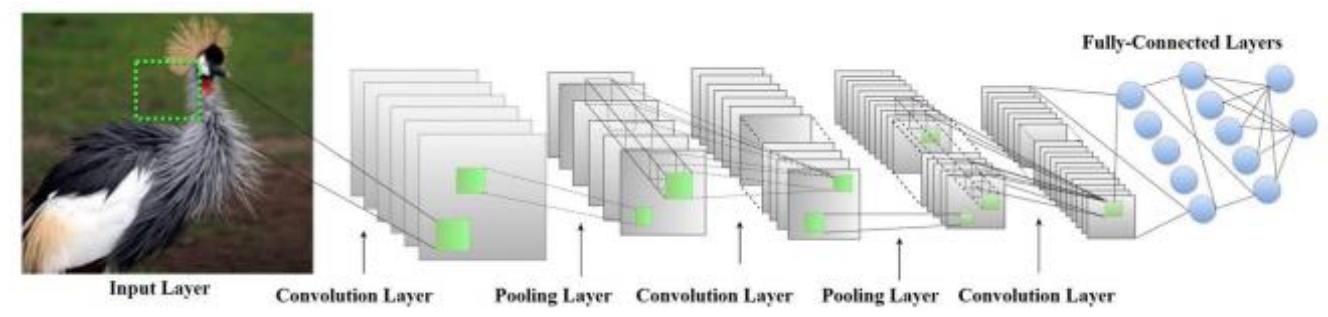

Gambar 3: Fully Connected Layer (Al-Waisy et al., 2018).

3) Membandingkan model

Setelah pemodelan data training dibangun, langkah selanjutnya adalah menentukan jumlah epochs. Optimasi adam digunakan untuk meningkatkan akurasi dari model yang telah dibuat. Adam adalah algoritma optimisasi tingkat pembelajaran adaptif lain. Nama "Adam" berasal dari frasa "adaptive moments" (Kingma \& Ba, 2014). Adam merupakan kombinasi RMSProp dan momentum dengan beberapa perbedaan penting. Pertama momentum digabungkan secara langsung sebagai perkiraan momen orde pertama (dengan bobot eksponensial) dari gradien. Kedua, Adam memasukkan koreksi-koreksi bias ke estimasi momenmomen orde pertama (momentum term) dan momen-momen orde kedua (tidak terpusat) untuk menjelaskan inisialisasi origin. Output dari pemilihan jumlah epochs optimasi adalah meningkatnya akurasi serta menurunnya loss function pada data training walapun menggunakan pemodelan CNN yang sama.

4) Klasifikasi data test

Dari hasil pemodelan dengan optimasi terbaik, kemudian dilakukan pengujian untuk mengklasifikasikan data test yang juga merupakan citra chest radiograph. Hasil dari klasifikasi dapat dilihat melalui confusion matix dan akurasi yang didapat 
dari hasil klasifikasi data test. Confusion matrix adalah matrix yang merepresentasikan hasil klasifikasi pada suatu dataset (Pedregosa et al., 2011).

Tabel 1: Confusion Matrix binner.

\begin{tabular}{lll}
\hline Kelas & Positif & Negatif \\
\hline Positif & Positif Benar (PB) & Negatif Salah (NS) \\
Negatif & Positif Salah (PS) & Negatif Benar (NB) \\
\hline
\end{tabular}

Terdapat beberapa rumus umum yang dapat digunakan untuk menghitung performa klasifikasi. Hasil dari nilai accuracy, presision dan recall bisa ditampilkan dalam presentase (Tabel 1).

a. Accuracy adalah jumlah proporsi prediksi yang benar. Adapun rumus perhitungan akurasi dapat dilihat dari persamaan dibawah ini.

$$
\text { Accuracy }=\frac{P B+N B}{P B+P S+N B+N S}
$$

b. Presisi adalah rasio PB / (PB + PS). Presisi secara intuitif adalah kemampuan classifier untuk tidak memberi label positif sebagai sampel yang negatif.

c. Recall atau penarikan kembali adalah rasio PB / (PB + NS). Penarikan secara intuitif adalah kemampuan classifier untuk menemukan semua sampel positif.

\section{Hasil dan Pembahasan}

Berikut adalah hasil dan pembahasan dari masing-masing tahap:

1) Preprocessing Data

a. Pembagian data. Data mentah yang di dapat kemudian di ambil sampling dengan menggunakan probability samping yaitu simple random sampling. Tahap preprocessing data sendiri meliputi pemisahan data menjadi data training, data validasi, dan data test disajikan pada Tabel 2.

Tabel 2: Partisi data.

\begin{tabular}{cccc}
\hline Bagian & Jumlah Data & Kondisi & Jumlah \\
\hline Data training & 2000 & Normal & 1000 \\
& & Pneumonia & 1000 \\
Data validasi & 200 & Normal & 100 \\
Data test & 200 & Pneumonia & 100 \\
& & Normal & 100 \\
& & Pneumonia & 100 \\
& Total & & 2400
\end{tabular}

b. Konversi ke array. Data yang telah dipisahkan ke dalam tiga set data kemudian dikonversi ke dalam array terlebih dahulu, hal ini dikarenakan komputer hanya bisa membaca sebuah citra gambar sebagai susunan angka yang kemudian disebut sebagai array. Konversi gambar juga akan membagi setiap gambar menjadi tiga bagian warna atau depth yaitu red, green, blue (RGB). Gambar 4 adalah sampel dari konversi sebuah citra menjadi array, dimana array yang ditampilkan adalah $5 \times 5$ susunan angka pertama setiap bagian warna. Data dalam bentuk array inilah yang akan diproses dalam CNN. Array diplotkan kembali menjadi sebuah gambar terpisah berdasarkan bagian warna untuk melihat setiap bagiannya. 


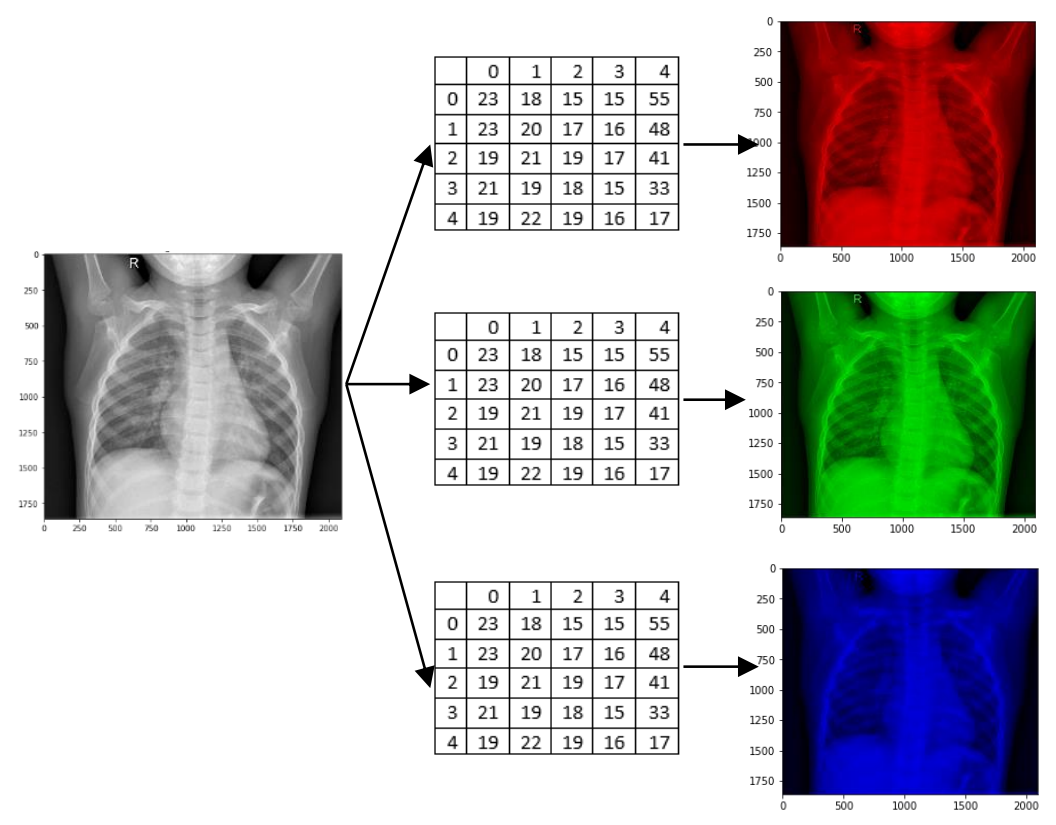

Gambar 4: Sampel konversi ke array.

2) Pemodelan CNN

Pembangunan model CNN terdiri dari beberapa tahap penggulangan antara lapisan konvolusi dan lapisan pooling yang diakhiri dengan lapisan fully connected. Tabel 3 menjelaskan bahwa model dibangun dari empat kali perulangan lapisan konvolusi dan pooling sebelum diakhiri dengan lapisan fully connected. Berdasarkan output diatas didapatkan parameter total 88.699.969, parameter yang dilatih 88.699 .969 serta tidak ada parameter yang tidak dilatih.

Tabel 3: Pembangunan model CNN.

\begin{tabular}{lcc}
\hline \multicolumn{1}{c}{ Layer } & Output Shape & Param \\
\hline Layer konvolusi & $(222,222,32)$ & 896 \\
Max pooling & $(111,111,32)$ & 0 \\
Layer konvolusi & $(109,109,64)$ & 18.496 \\
Max pooling & $(54,54,64)$ & 0 \\
Layer konvolusi & $(52,52,128)$ & 73.856 \\
Max pooling & $(26,26,128)$ & 0 \\
Flatten & $(86528)$ & 0 \\
Dropout & $(86528)$ & 0 \\
Dense & $(1024)$ & 88.605 .696 \\
Dense & $(1)$ & 1025 \\
Total params & & $\mathbf{8 8 . 6 9 9 . 9 6 9}$ \\
Trainable params & & $\mathbf{8 8 . 6 9 9 . 9 6 9}$ \\
Non-trainable & & $\mathbf{0}$ \\
params & & \\
\hline
\end{tabular}

3) Membandingkan model

Tahapan selanjutnya adalah pengaplikasian model yang dibentuk ke dalam data training serta data validasi dengan beberapa pemilihan banyaknya epochs pada saat mulai konvergen. Setiap epochs berjalan melalui 16 langkah. 
Tabel 4: Perbandingan epochs.

\begin{tabular}{lccc}
\hline \multirow{2}{*}{ Keterangan } & \multicolumn{3}{c}{ Maksimum epochs } \\
\cline { 2 - 4 } & 50 & 75 & 100 \\
\hline Akurasi data training & $98,26 \%$ & $99,12 \%$ & $98,98 \%$ \\
Loss function data training & 0.0913 & 0.0714 & 0.0646 \\
Akurasi data validsai & $96,00 \%$ & $96.50 \%$ & $97.00 \%$ \\
Loss function data validasi & 0.2019 & 0.1506 & 0.1484 \\
\hline
\end{tabular}

Pengaplikasian model ke dalam data training dan data validasi dioptimasi dengan menggunakan adaptive momentum atau adam. Adam dipilih karena hasil dari penyempurnaan optimasi dalam deep learning yang sudah ada sebelumnya. Optimasi dilakukan untuk meningkatkan learning rate yang berdampak pada peningkatan akurasi.

Tabel 4 menampilkan output masing-masing pemilihan epochs. Akurasi tertinggi sebesar $99.12 \%$ pada epochs 75 , Sedangkan loss function terendah 0.0646 pada data training pada epochs 100 . Akurasi tertinggi sebesar $97,00 \%$ dan loss function terendah 0,1484 pada data validasi dengan 100 epochs, maka model yang dipilih menggunakan 100 epochs. Gambar 5 menunjukan tingkat akurasi dan loss function data training dan validasi dari perjalanan epochs pertama hingga epochs terakhir.
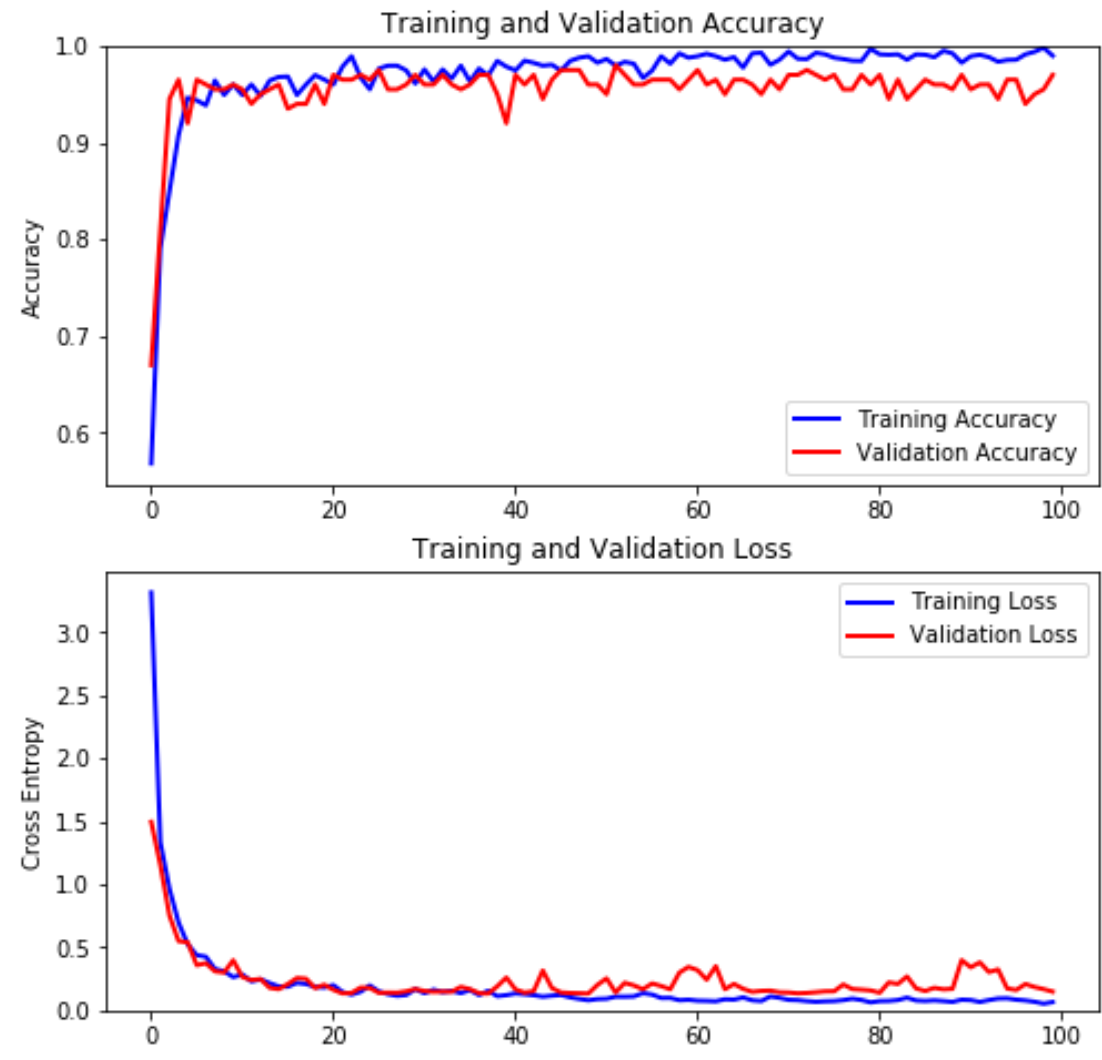

Gambar 5: Plot akurasi dan loss function

Gambar 5 menjelaskan bahwa akurasi dari model cenderung naik dan loss function cenderung menurun untuk data training, sedangkan untuk data validasi, akurasi dari model cenderung turun dan loss function cenderung naik.Berdasarkan plot akurasi menuju arah konvergen setelah epochs ke-lima . 
4) Klasifikasi

Model yang telah diperoleh kemudian di uji ke dalam data test sehingga didapat output sebagai berikut. Gambar 6 menjelaskan bahwa model yang telah dibangun dapat mengklasifikasi paru-paru normal secara benar sebanyak 98 data dan dua datasalah han, sedangkan untuk paru-paru dengan kondisi pneumonia, model mampu menglasifikasi 58 data secara benar dan 42 data salah. Klasifikasi dari data test lebih jelas dapat dilihat dari laporan hasil klasifikasi yang ditunjukan pada Tabel 5 berikut.

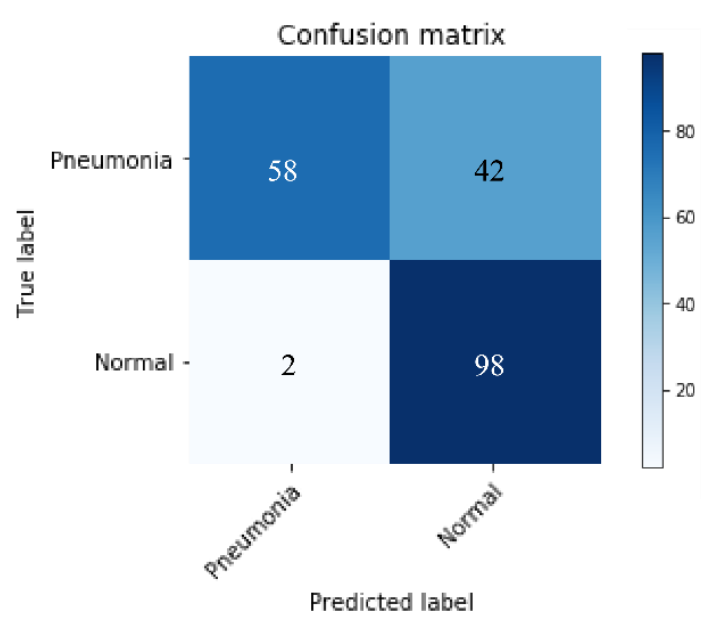

Gambar 6: Confusion Matrix

Tabel 5: Laporan klasifikasi.

\begin{tabular}{ccc}
\hline & Precision & Recall \\
\hline Pneumonia & 0.97 & 0.58 \\
Normal & 0.70 & 0.98 \\
Akurasi & & 0.78 \\
\hline
\end{tabular}

Tabel 5 menjelaskan presisi dari paru-paru pneumonia sebesar 97\% yang berarti bahwa kemampuan classifier untuk tidak memberi label pneumonia sebagai sampel normal sebesar $97 \%$, sedangkan untuk normal sebesar $70 \%$. Recall pada paru-paru pneumonia sebesar $58 \%$ yang berarti bahwa kemampuan classifier untuk menemukan semua sampel pneumonia sebesar $58 \%$.dan untuk paru-paru normal sebesar $98 \%$, Tingkat akurasi secara keseluruhan sebesar $78 \%$. Hasil akurasi lebih kecil dibanding dengan penelitian Saravia, et al. (2019) sebesar 95,30\% dikarenakan arsitektur model yang dibangun menggunakan base model yang sudah ada.

\section{Simpulan}

Simpulan dari penelitian ini adalah model yang dibangun dengan menggunakan 100 epochs menghasilkan akurasi pada data training sebesar $98,98 \%$ dan $97,00 \%$ pada data validasi. Model yang dibentuk kemudian di uji ke dalam data test dengan tingkat akurasi $78 \%$ dengan rincian paru-paru normal secara benar diklasifikasikan sebanyak 98 data dan terdapat dua data salah, sedangkan untuk paru-paru dengan kondisi pneumonia, model mampu menglasifikasi 58 data secara benar dan 42 data salah. 


\section{Daftar Pustaka}

Al-Waisy, A. S., Qahwaji, R., Ipson, S., Al-Fahdawi, S., \& Nagem, T. A. (2018). A multibiometric iris recognition system based on a deep learning approach. Pattern Analysis and Applications, 21(3): 783-802.

Cireşan, D., Meier, U., \& Schmidhuber, J. (2012). Multi-column deep neural networks for image classification. Retrieved from IEEE Computer Society Conference on Computer Vision and Pattern Recognition website: https://arxiv.org/abs/1202.2745

Goodfellow, I., Bengio, Y., \& Courville, A. (2016). Deep learning. Massachusetts (US): MIT press.

Kermany, D., Zhang, K., \& Goldbaum, M. (2018). Labeled optical coherence tomography (OCT) and chest X-Ray images for classification, Mendeley Data, vol. 2 (2018). Mendeley Data.

Kingma, D. P., \& Ba, J. (2014). Adam: A method for stochastic optimization. 3rd International Conference for Learning Representations. Presented at the 3rd International Conference for Learning Representations, San Diego (US). Retrieved from https://arxiv.org/abs/1412.6980

Li, F. F., Johnson, J., \& Yeung, S. (2019). Convolutional neural networks (Lecture notes). California (US): Computer Science, Stanford University.

Oyedotun, O., \& Khashman, A. (2017). Iris nevus diagnosis: convolutional neural network and deep belief network. Turkish Journal of Electrical Engineering \& Computer Sciences, 25(2): 1106-1115.

Pedregosa, F., Varoquaux, G., Gramfort, A., Michel, V., Thirion, B., Grisel, O., ... Dubourg, V. (2011). Scikit-learn: Machine learning in Python. Journal of Machine Learning Research, 12(Oct): 2825-2830.

Rizal, A., Hidayat, R., \& Nugroho, H. A. (2017). Entropy measurement as features extraction in automatic lung sound classification. 2017 International Conference on Control, Electronics, Renewable Energy and Communications (ICCREC), 93-97. Yogyakarta (ID): IEEE.

Romero, A., Gatta, C., \& Camps-Valls, G. (2016). Unsupervised deep feature extraction for remote sensing image classification. IEEE Transactions on Geoscience and Remote Sensing, 54(3): 1349-1362.

Santos, A. dos, Pereira, B. de B., Seixas, J. de, Mello, F. C. Q., \& Kritski, A. L. (2007). Neural networks: an application for predicting smear negative pulmonary tuberculosis. In Advances in statistical methods for the health sciences (pp. 275287). Springer.

Saraiva, A., Ferreira, N., Sousa, L., Carvalho da Costa, N., Sousa, J., Santos, D., ... Soares, S. (2019). Classification of Images of Childhood Pneumonia using Convolutional Neural Networks. 6th International Conference on Bioimaging, 112119. https://doi.org/10.5220/0007404301120119

Scherer, D., Müller, A., \& Behnke, S. (2010). Evaluation of pooling operations in convolutional architectures for object recognition. International Conference on Artificial Neural Networks, 92-101. Berlin (DE): Springer.

[WHO] World Health Organization. (2016). Pneumonia. Retrieved from http://www.who.int/en/ 